Prepared in cooperation with Douglas County Environmental Services and the Nebraska Environmental Trust

\title{
Water Balance Monitoring for Two Bioretention Gardens in Omaha, Nebraska, 2011-14
}

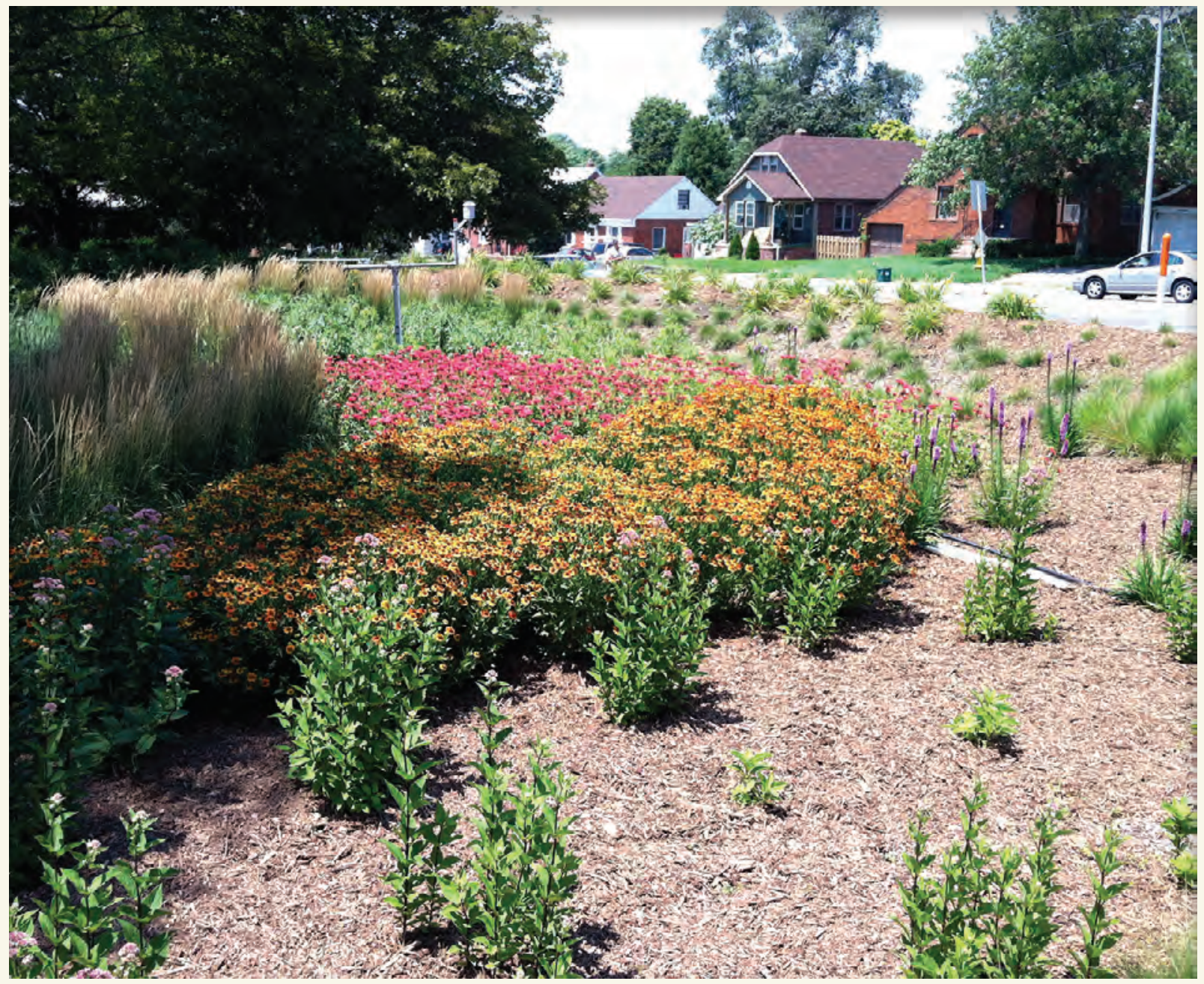

Scientific Investigations Report 2015-5188

U.S. Department of the Interior

U.S. Geological Survey 
Front cover. Eastern Nebraska Office on Aging bioretention garden (photograph taken by Kent Holm, Douglas County Environmental Services, June 26, 2012.

Back cover. Top, Douglas County Health Center bioretention garden 1 (photograph taken by David Rus, U.S. Geological Survey, June 17, 2011. Middle, Douglas County Health Center bioretention garden 1 (photograph taken by Kent Holm, Douglas County Environmental Services, August 3, 2011. Bottom, Eastern Nebraska Office on Aging bioretention garden (photograph taken by Kent Holm, Douglas County Environmental Services, June 17, 2011. 


\section{Water Balance Monitoring for Two Bioretention Gardens in Omaha, Nebraska, 2011-14}

By Kellan R. Strauch, David L. Rus, and Kent E. Holm

Prepared in cooperation with Douglas County Environmental Services and the Nebraska Environmental Trust

Scientific Investigations Report 2015-5188 


\title{
U.S. Department of the Interior SALLY JEWELL, Secretary
}

\section{U.S. Geological Survey Suzette M. Kimball, Director}

\author{
U.S. Geological Survey, Reston, Virginia: 2016
}

For more information on the USGS - the Federal source for science about the Earth, its natural and living resources, natural hazards, and the environment—visit http://www.usgs.gov or call 1-888-ASK-USGS.

For an overview of USGS information products, including maps, imagery, and publications, visit http://www.usgs.gov/pubprod/.

Any use of trade, firm, or product names is for descriptive purposes only and does not imply endorsement by the U.S. Government.

Although this information product, for the most part, is in the public domain, it also may contain copyrighted materials as noted in the text. Permission to reproduce copyrighted items must be secured from the copyright owner.

Suggested citation:

Strauch, K.R., Rus, D.L., Holm, K.E., 2016, Water balance monitoring for two bioretention gardens in Omaha, Nebraska, 2011-14, U.S. Geological Survey Scientific Investigation Report 2015-5188, 19 p., http://dx.doi. org/10.3133/sir20155188.

ISSN 2328-0328 (online) 


\section{Acknowledgments}

The authors also thank the Douglas County Health Center and the Eastern Nebraska Office on Aging for granting access to their properties for this study. 



\section{Contents}

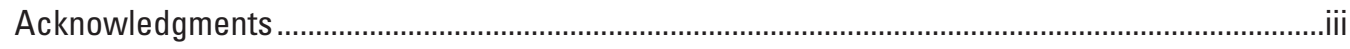

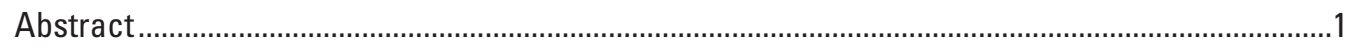

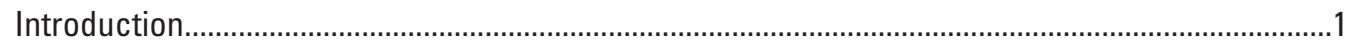

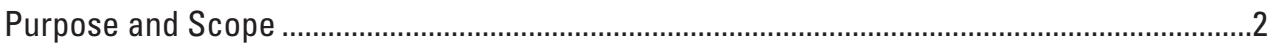

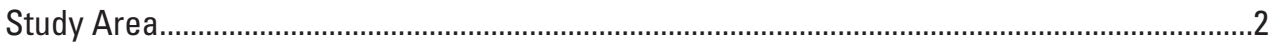

Douglas County Health Center Bioretention Garden .......................................................2

Eastern Nebraska Office on Aging Bioretention Garden .................................................

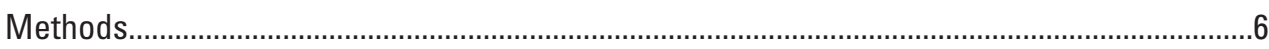

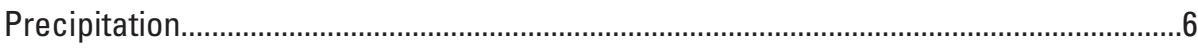

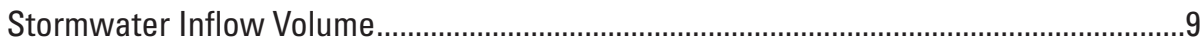

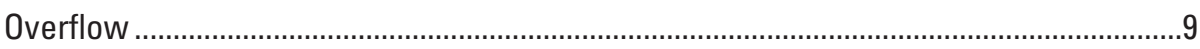

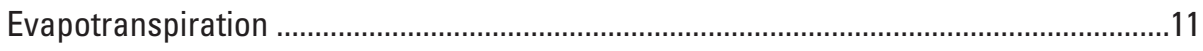

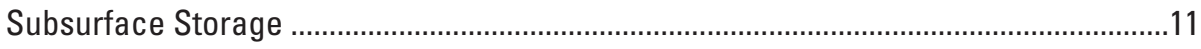

Rainfall Event Duration Determination ..........................................................................12

Water Balance Monitoring............................................................................................................

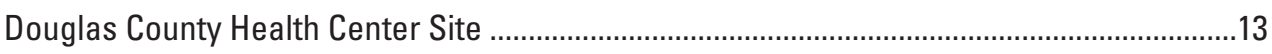

Performance on an Event Basis ................................................................................

Monitoring Period Summary .......................................................................................15

Eastern Nebraska Office on Aging Site ...........................................................................15

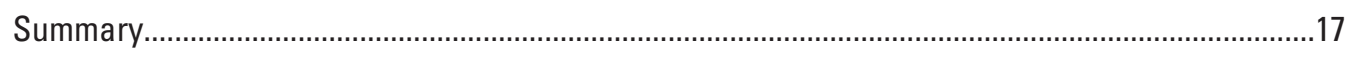

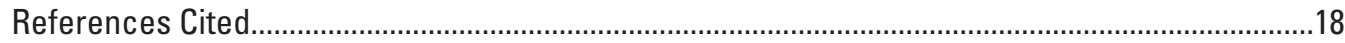

\section{Figures}

1. Map showing location of bioretention garden study sites in Omaha, Nebraska ..............3

2. Bioretention garden at the Douglas County Health Center site, Omaha, Nebraska .........4

3. Bioretention garden at the Eastern Nebraska Office on Aging site, Omaha, Nebraska .....................................................................................................................

4. A slotted grate affects overflow estimates at the Douglas County Health Center bioretention garden ........................................................................................................10

5. Graphs showing performance measures at the bioretention garden at the Douglas

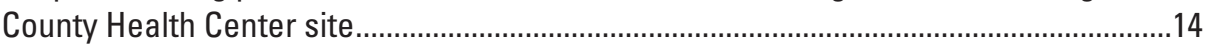

6. Graph showing relation between peak inflow rate and peak outflow rate for measured events at the Douglas County Health Center bioretention garden..

7. Graph showing annual water balance components for measured events during 2011-14, normalized to the bioretention garden area at the Douglas County Health Center site

8. Graph showing annual water balance components for all events during 2011-14, normalized to the bioretention garden area at the Eastern Nebraska Office on Aging site 


\section{Tables}

1. Summary of plant species and calculated landscape coefficient for the bioretention gardens at the Douglas County Health Center and Eastern Nebraska Office on Aging sites

2. Monitoring period summary of water balance components for measured events during 2011-14 for the bioretention garden at the Douglas County Health Center site

3. Monitoring period summary of water balance components for all events during 2011-14 for the bioretention garden for the Eastern Nebraska Office on Aging site......17

\section{Conversion Factors}

Inch/Pound to International System of Units

\begin{tabular}{lcl}
\hline \multicolumn{1}{c}{ Multiply } & By & To obtain \\
\hline inch (in.) & Length & \\
foot $(\mathrm{ft})$ & 2.54 & centimeter $(\mathrm{cm})$ \\
mile $(\mathrm{mi})$ & 0.3048 & meter $(\mathrm{m})$ \\
& 1.609 & kilometer $(\mathrm{km})$ \\
\hline acre & Area & \\
square foot $\left(\mathrm{ft}^{2}\right)$ & 4,047 & square meter $\left(\mathrm{m}^{2}\right)$ \\
\hline & 0.09290 & square meter $\left(\mathrm{m}^{2}\right)$ \\
\hline cubic foot $\left(\mathrm{ft}^{3}\right)$ & Volume & cubic decimeter $\left.(\mathrm{dm})^{3}\right)$ \\
cubic foot $\left(\mathrm{ft}^{3}\right)$ & 28.32 & cubic meter $\left(\mathrm{m}^{3}\right)$ \\
\hline
\end{tabular}

Temperature in degrees Celsius $\left({ }^{\circ} \mathrm{C}\right)$ may be converted to degrees Fahrenheit $\left({ }^{\circ} \mathrm{F}\right)$ as ${ }^{\circ} \mathrm{F}=(1.8 \times$ $\left.{ }^{\circ} \mathrm{C}\right)+32$.

Temperature in degrees Fahrenheit $\left({ }^{\circ} \mathrm{F}\right)$ may be converted to degrees Celsius $\left({ }^{\circ} \mathrm{C}\right)$ as ${ }^{\circ} \mathrm{C}=\left({ }^{\circ} \mathrm{F}-\right.$ 32) / 1.8 .

\section{Datum}

Horizontal coordinate information is referenced to the North American Datum of 1983 (NAD 83). 


\title{
Water Balance Monitoring for Two Bioretention Gardens in Omaha, Nebraska, 2011-14
}

\author{
By Kellan R. Strauch, ${ }^{1}$ David L. Rus, ${ }^{1}$ and Kent E. Holm²
}

\section{Abstract}

Bioretention gardens are used to help mitigate stormwater runoff in urban settings in an attempt to restore the hydrologic response of the developed land to a natural predevelopment response in which more water is infiltrated rather than routed directly to urban drainage networks. To better understand the performance of bioretention gardens in facilitating infiltration of stormwater in eastern Nebraska, the U.S. Geological Survey, in cooperation with the Douglas County Environmental Services and the Nebraska Environmental Trust, assessed the water balance of two bioretention gardens located in Omaha, Nebraska by monitoring the amount of stormwater entering and leaving the gardens. One garden is on the Douglas County Health Center campus, and the other garden is on the property of the Eastern Nebraska Office on Aging.

For the Douglas County Health Center, bioretention garden performance was evaluated on the basis of volume reduction by comparing total inflow volume to total outflow volume. The bioretention garden reduced inflow volumes from a minimum of 33 percent to 100 percent (a complete reduction in inflow volume) depending on the size of the event. Although variable, the percent reduction of the inflow volume tended to decrease with increasing total event rainfall. To assess how well the garden reduces stormwater peak inflow rates, peak inflows were plotted against peak outflows measured at the bioretention garden. Only 39 of the 255 events had any overflow, indicating 100 percent peak reduction in the other events. Of those 39 events having overflow, the mean peak reduction was 63 percent.

No overflow events were recorded at the bioretention garden at the Eastern Nebraska Office on Aging; therefore, data were not available for an event-based overflow analysis. Monitoring period summary of the water balance at both bioretention gardens indicates that most of the stormwater in the bioretention gardens is stored in the subsurface.

Evapotranspiration was attributed to a small percentage of the outputs on an annual basis ( 3 percent at Douglas County Health Center site and 5 percent at Eastern Nebraska Office on Aging site), which indicates that vegetative water uptake is not a primary factor in the water budget.

\footnotetext{
${ }^{1}$ U.S. Geological Survey

${ }^{2}$ Douglas County Environmental Services
}

\section{Introduction}

Urbanization can radically alter the flow regime of a stream system by creating impermeable areas that favor stormwater runoff instead of infiltration and by constructing drainage networks that quickly transport the stormwater out of the urban area. When coupled with the pollutants typically associated with urbanization, this disturbance to the flow regime typically degrades the quality of the urban stream (National Research Council, 2009). Areas that are drained by combined sewer systems - where stormwater sewers (drainage networks that drain surface water from impervious land) and sanitary sewers (drainage networks in which sewage from houses and commercial buildings are collected and transported to be treated) are combined in one pipe and can be released untreated into streams during rainfall events-present a greater challenge to stormwater management because of the additional human-health threats associated with sanitary sewage from combined sewer systems. In response, stormwater best management practices are used to reduce stormwater effects. A stormwater best management practice is a "technique, process, activity, or structure to reduce the pollutant content of stormwater discharge, and could be implemented singly or in tandem to maximize effectiveness" (Fletcher and others, 2015).

The bioretention garden is one type of stormwater best management practice. In a typical bioretention garden design, stormwater is directed from impervious surfaces into a vegetated basin with an underdrain (Water Environment Federation, 2012). The soils are usually amended to promote plant growth and enhance evapotranspiration processes and nutrient uptake. The underdrain is lined by a variety of porous media and generally functions as a filter for the stormwater. The purpose of the bioretention gardens is to attenuate and delay peak flows and to reduce the total volume of stormwater runoff into the combined storm sewer system. Natural processes are used to infiltrate, filter, store, evaporate, and detain runoff similar to how the water would have been processed in a more natural setting. In the case of combined sewer systems such as in Omaha, Nebraska, bioretention gardens have the potential to decrease the frequency and magnitude of instances when untreated sewage is released into receiving waters. 
Although bioretention gardens have been used for several years in the United States, questions exist regarding their effectiveness locally. To better understand the performance of bioretention gardens in eastern Nebraska, the U.S. Geological Survey, in cooperation with Douglas County Environmental Services and the Nebraska Environmental Trust, assessed the water balance of two bioretention gardens by monitoring the amount of stormwater entering and leaving the gardens during 2011-14.

\section{Purpose and Scope}

The purpose of this report is to present the results of water balance monitoring for two bioretention gardens in Omaha, Nebraska. Water balance data were collected at the two bioretention gardens from May through October in 2011 and from April through October in 2012, 2013, and 2014.

\section{Study Area}

In Omaha, Nebraska, two bioretention gardens at two different locations were constructed to receive stormwater from adjacent buildings and parking lots (fig. 1). The two bioretention gardens are in the central part of the city, approximately 0.5 mile apart. One garden is on the east side of the Douglas County Health Center (DCHC) campus approximately two blocks south of the intersection between 40th and Pacific Streets, and the other garden is on the Eastern Nebraska Office on Aging (ENOA) property at the southwest corner of the intersection between 42nd and Center Streets (fig. 1). The mean annual temperature in Omaha during 1981-2010 was 51.1 degrees Fahrenheit with seasonal means ranging from 85.2 degrees Fahrenheit in the summer to 16.1 degrees Fahrenheit in the winter (National Oceanic and Atmospheric Administration, 2015a). The mean annual precipitation during 1981-2010 was 30.6 inches (in.) with most of the precipitation falling in the spring, summer, and autumn.

Both bioretention gardens were constructed in soils consisting of firm to stiff clay fill material that overlie a firm clay of low plasticity (Peorian Loess; Edward M. Schmackenberg, Olsson Associates, written commun., 2010). Each garden has an underdrain in the bottom of the bioretention garden and drains into the combined sewer system. The underdrain consists of a 4-in. diameter perforated pipe that is surrounded by coarse gravel and wrapped in a geotextile filter fabric (Paul Woodward, Olsson Associates, written commun., 2010). The gravel-wrapped pipe rests in a 2 - by 2 -foot (ft) infiltration trench that is filled with an even mixture of fine sand and compost. The remainder of the bioretention cell was covered with 6 in. of compost that was tilled into the native soil. The rain gardens were constructed in July 2010 and planting was finished in August 2010.

A feature of the underdrain is the inclusion of an adjustable valve that allows for the controlled drainage of the bioretention garden. The valve is adjusted to maximize the detention capacity of the bioretention garden and still preserve the ability to drain the garden in 24-48 hours (City of Omaha, 2014). To simplify the measurements required for the water balance equation, the underdrain valves remained closed for the duration of the monitoring period. Each bioretention garden has an overflow standpipe that is connected to the storm sewer and is set at a height to ensure that the bioretention garden's berms are not overtopped, which corresponds to 0.39 and $1.66 \mathrm{ft}$ above the land surface of the DCHC and the ENOA bioretention gardens, respectively.

\section{Douglas County Health Center Bioretention Garden}

The DCHC bioretention garden consists of two gardens joined together in series (fig. $2 A, 2 B, 2 C$ ). Stormwater runoff is directed into an inflow channel and then enters garden 1. If the ponding depth in garden 1 exceeds the height of an intermediate pipe connecting the two gardens (corresponding to a height of $0.39 \mathrm{ft}$ above the surface of the bioretention garden 1), the excess water flows into garden 2 . If the ponding depth in garden 2 exceeds the height of the overflow standpipe, the excess water flows to the combined sewer. Unfortunately, an undocumented drainpipe at the bottom of garden 2 was uncovered near the end of the monitoring period (fig. 2C). The drain was originally covered by soil but became exposed during the course of the study; therefore, an unmeasured volume of water drained from garden 2 to the storm drain. As a result, the water balance was computed on flows into and outputs from bioretention garden 1 only; garden 2 was excluded from all computations.

Bioretention garden 1 occupies a surface area of about 2,100 square feet $\left(\mathrm{ft}^{2}\right)$ and has a surface storage volume of 700 cubic feet $\left(\mathrm{ft}^{3}\right)$, corresponding to the pool storage before the garden overflows. The DCHC bioretention garden receives stormwater from 1.3 acres $\left(56,600 \mathrm{ft}^{2}\right)$; therefore, garden 1 provides $538 \mathrm{ft}^{3}$ of storage per acre of drainage area. The drainage area is almost completely impervious and consists of the adjacent building rooftop and parking lot (fig. $2 A$ ). The runoff from the rooftop is collected into downspouts that direct the flow to the parking lot to the east and is then redistributed into sheet flow on the parking lot. The stormwater continues flowing east on the parking lot to the curb that separates the bioretention garden from the parking lot (fig. $2 B$ ). Once the flow reaches the curb, the flow is channeled into the bioretention garden at the inlet and routed through the flume into the bioretention garden.

\section{Eastern Nebraska Office on Aging Bioretention Garden}

The ENOA bioretention garden initially had a drainage area of about 0.48 acre; however, after the initial 2 years of monitoring (2011-12), modifications were made at the bioretention garden that increased the drainage area to 0.78 acre 


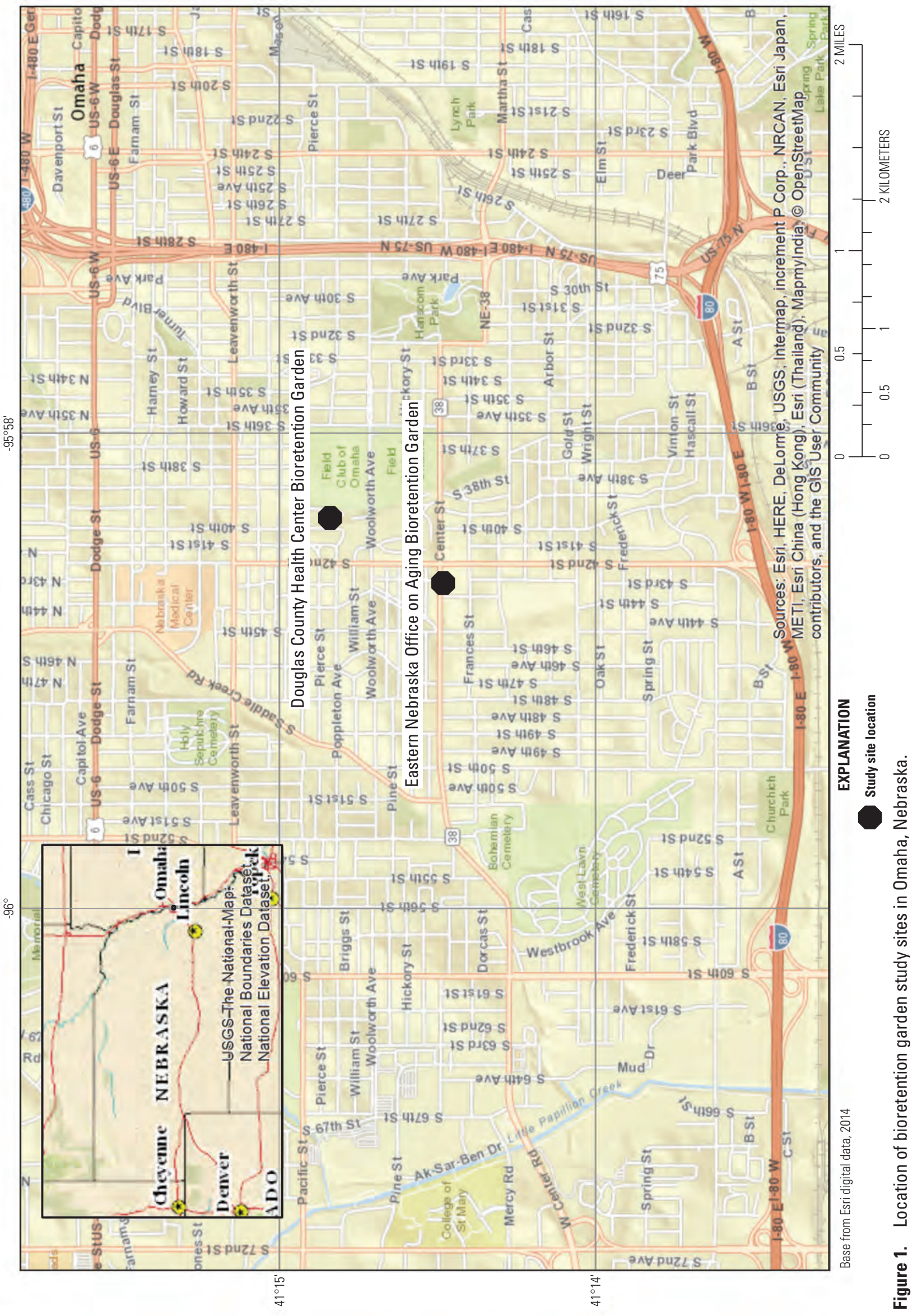




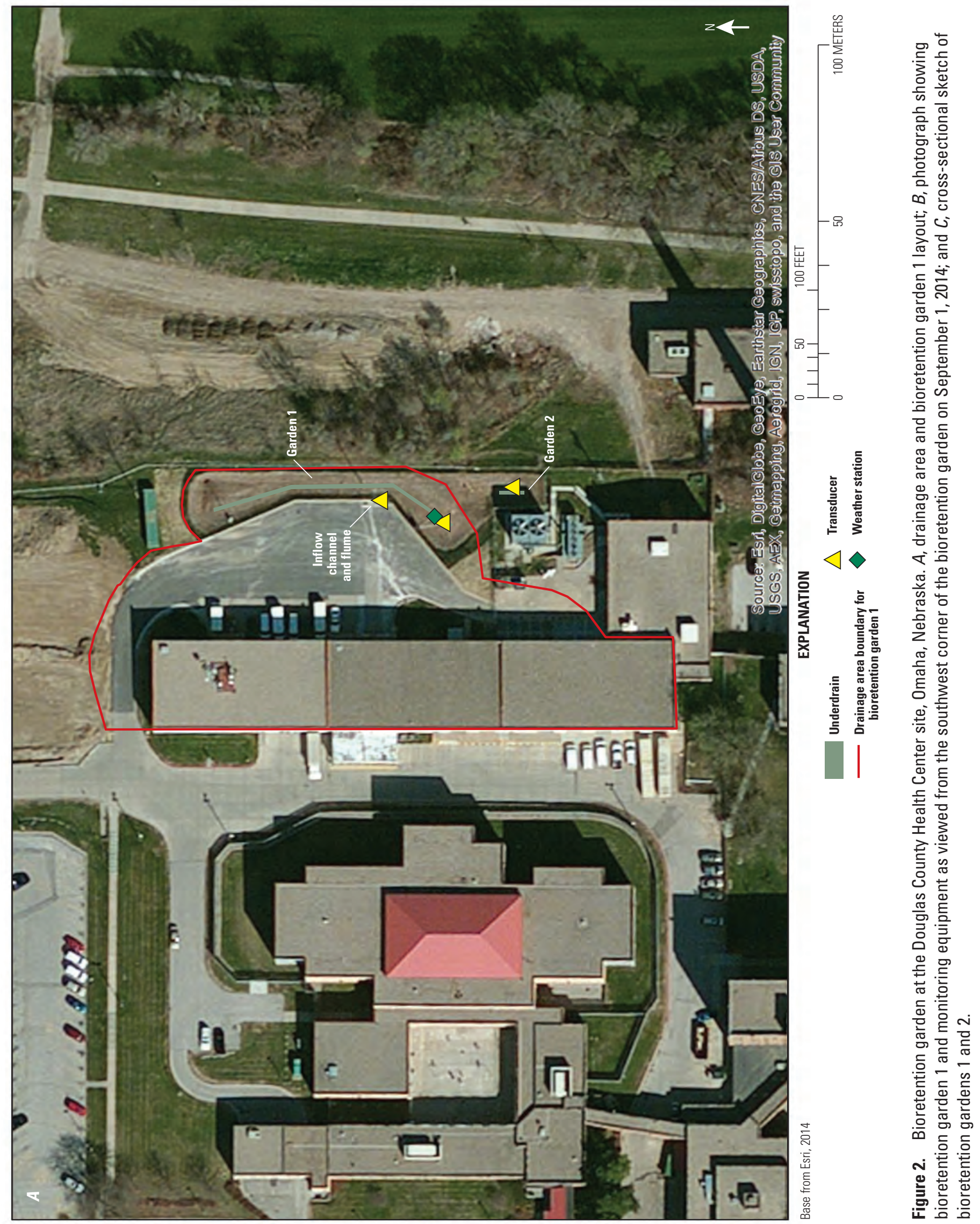



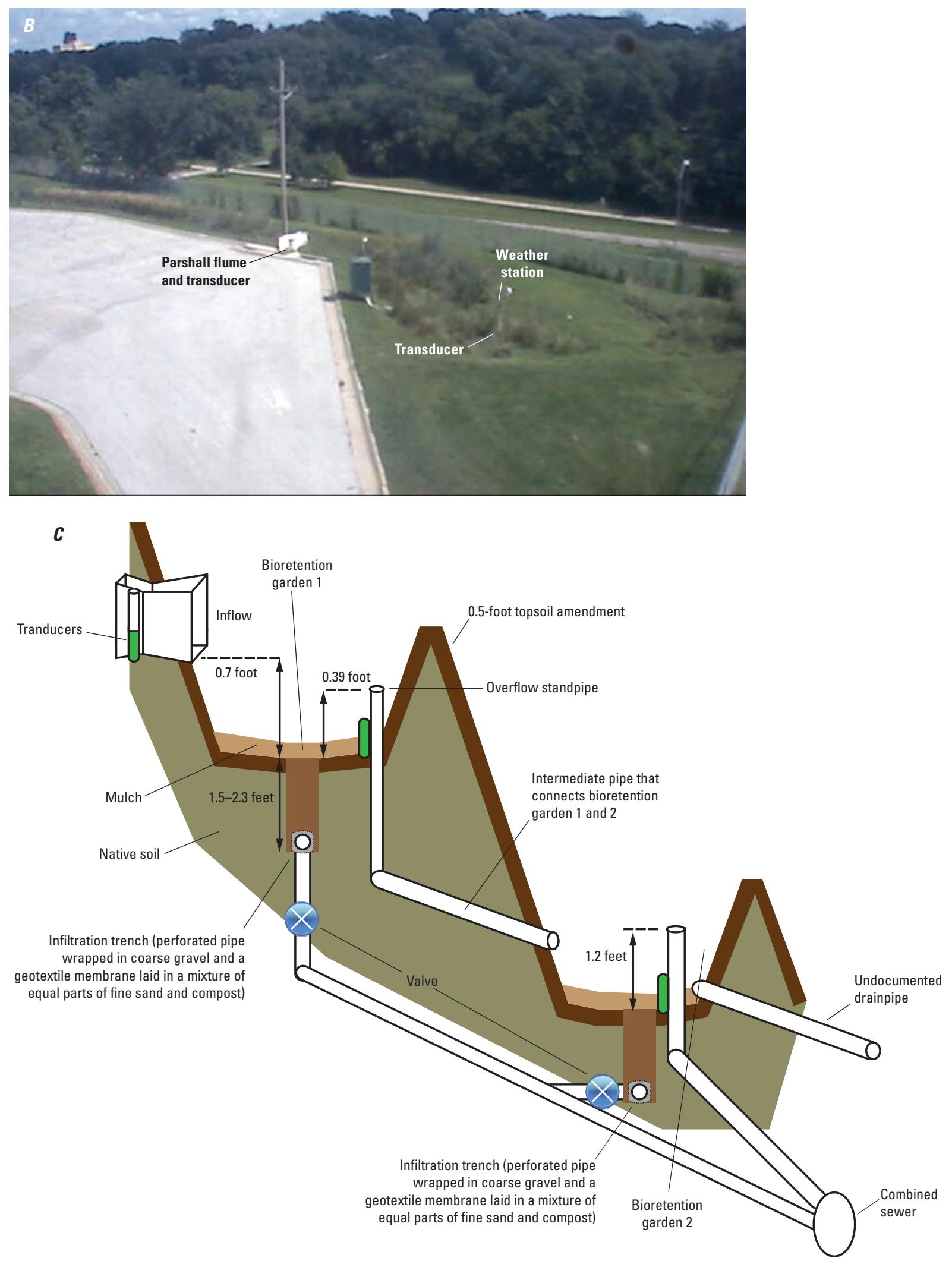

Vertical scale greatly exaggerated

Figure 2. Bioretention garden at the Douglas County Health Center site, Omaha, Nebraska. $A$, drainage area and bioretention garden 1 layout; $B$, photograph showing bioretention garden 1 and monitoring equipment as viewed from the southwest corner of the bioretention garden on September 1, 2014; and $C$, cross-sectional sketch of bioretention gardens 1 and 2.-Continued 
(fig. $3 A, 3 B, 3 C$ ) and increased the size of the parking lot drainage grates. The drainage area is almost completely impervious and consists of a part of the ENOA building's rooftop, surrounding parking lot, and an area of greenspace to the southeast of the building (fig. $3 A$ ). During construction of the bioretention garden, the rooftop downspouts associated with the western part of the ENOA building were disconnected from the storm sewer and routed to the bioretention garden's inflow channel. Unfortunately, the storm sewer connection to the downspouts associated with the eastern part of the roof could not be located. As a result, stormwater from the eastern part of the rooftop continues to drain to the storm sewer, and the corresponding area of the roof is not considered to contribute flow to the bioretention garden as shown as the noncontributing drainage area in figure $3 A$. The runoff flow for the parking lot is collected into three lateral parking lot drain grates (fig. $3 \mathrm{~A}$ ) and is then routed by pipe to the bioretention garden inflow channel. The ENOA bioretention garden has a surface area of about $2,900 \mathrm{ft}^{2}$ and a surface storage volume of $3,500 \mathrm{ft}^{3}$, which corresponds to the pool storage before the garden overflows; overflows are routed through a valved pipe to the combined sewer (fig. 3C). The ENOA site bioretention garden initially provided $7,300 \mathrm{ft}^{3}$ of storage per acre and $4,500 \mathrm{ft}^{3}$ of storage per acre after modifications were made at the site.

\section{Methods}

The general monitoring design corresponded to a water balance approach to characterize the inputs, outputs, and change in storage within the bioretention gardens. The water balance equation that was used in the monitoring period analysis can be represented numerically as follows:

$$
V_{P}+V_{S W}=V_{O F}+V_{U F}+V_{E T}+V_{S}+V_{S S}
$$

where

$V_{P} \quad$ is the volume of precipitation that falls directly into the bioretention garden,

$V_{S W} \quad$ is the volume of stormwater inflow to the bioretention garden,

$V_{O F} \quad$ is the volume of outflow from the bioretention garden by way of the overflow standpipe,

$V_{U F} \quad$ is the volume of outflow from the bioretention garden by way of the underdrain,

$V_{E T} \quad$ is the volume of evapotranspiration from the bioretention garden,

$V_{S} \quad$ is the change in volume of storage of ponded water within the bioretention garden, and

$V_{S S} \quad$ is the change in volume of storage in the subsurface within the bioretention garden (this includes any losses to infiltration, such as water that leaves the bottom of the rain garden and moves to the water table or out of the system horizontally).
The components of the water balance that were measured or calculated were $V_{P}, V_{S W}, V_{O F}$, and $V_{E T}$ Component $V_{U F}$ was assumed to be zero because the valves on the underdrains were closed at both bioretention gardens for the duration of the monitoring period. Although component $V_{S}$ could be estimated from water-level measurements within the bioretention gardens, $V_{S}$ was neglected from the water balance analyses because the depth of ponding at the end of the monitoring period was zero; therefore, change in storage of ponded water was always zero. The remaining component in equation $1, V_{S S}$, was estimated using equation 1 . Therefore, for the analysis in this report, the water balance inputs are $V_{P}$ and $V_{S W}$, and the outputs are $V_{O F}, V_{E T}$, and $V_{S S}$.

For the event-based analysis, only the components $V_{S W}$, $V_{P}$, and $V_{O F}$ were used. Although component $V_{S}$ was able to be estimated from water-level measurements within the bioretention gardens, $V_{S}$ was neglected from the event-based analyses because time periods were selected to represent rainfall events such that the change in storage of ponded water was always zero. Components $V_{E T}$ and $V_{S S}$ were not used in the event-based analysis because this analysis was used to characterize the reduction in stormwater volume and peak discharges to the storm sewer system primarily during time periods of overflow, and these components take place over longer time periods.

All of the components of the water balance were measured every 15 minutes during nonflow periods; however, $V_{S W}, V_{O F}$, and $V_{S}$ were measured every minute when flow was measureable or when water depths were higher than $0.03 \mathrm{ft}$ in each sensor (ponding). Collected data were stored using electronic data loggers and transmitted in near real time to the U.S. Geological Survey National Water Information System Web site (U.S. Geological Survey, 2015). All data collected for this study are available on the National Water Information System Web site (http://waterdata.usgs.gov/nwis/sw) using site number 411450095582201 for the DCHC site and site number 411429095583801 for the ENOA site. The monitoring methods associated with each of the water balance components are described in greater detail in the following sections.

\section{Precipitation}

Precipitation data were collected and summed in 15-minute intervals using a tipping bucket rain gage during the monitoring periods at both locations. The data from the rain gages were cross-checked with other nearby precipitation data to verify accuracy (National Oceanic and Atmospheric Administration, 2015b). Rainfall intensity information presented in the report was calculated using the 15-minute rainfall totals and scaling them to hourly rates of inches per hour. Precipitation data are presented in units of volume (for example, cubic feet) by multiplying the lengths (summed rainfall totals in inches converted to feet) by the surface area of the bioretention garden (in square feet). 

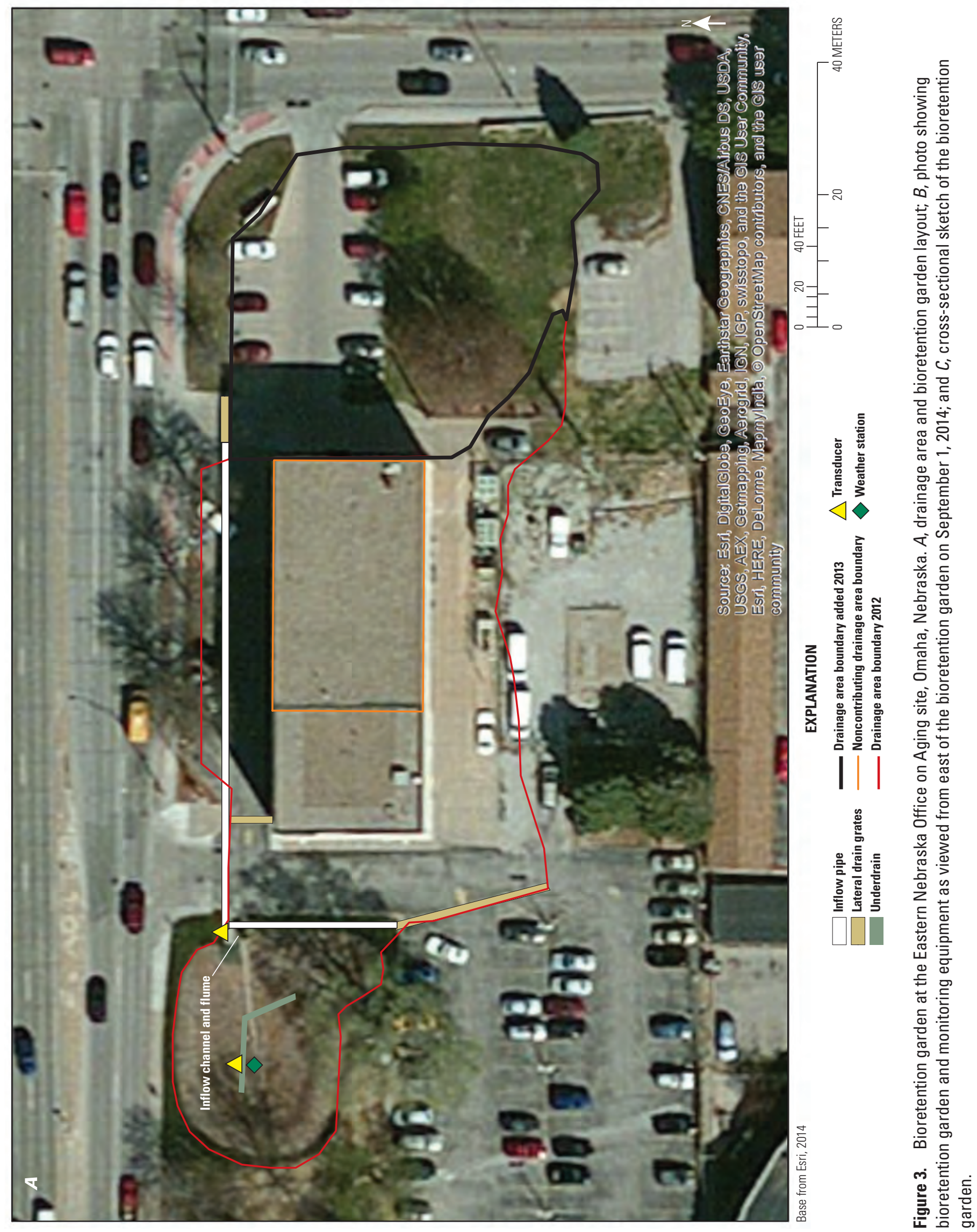

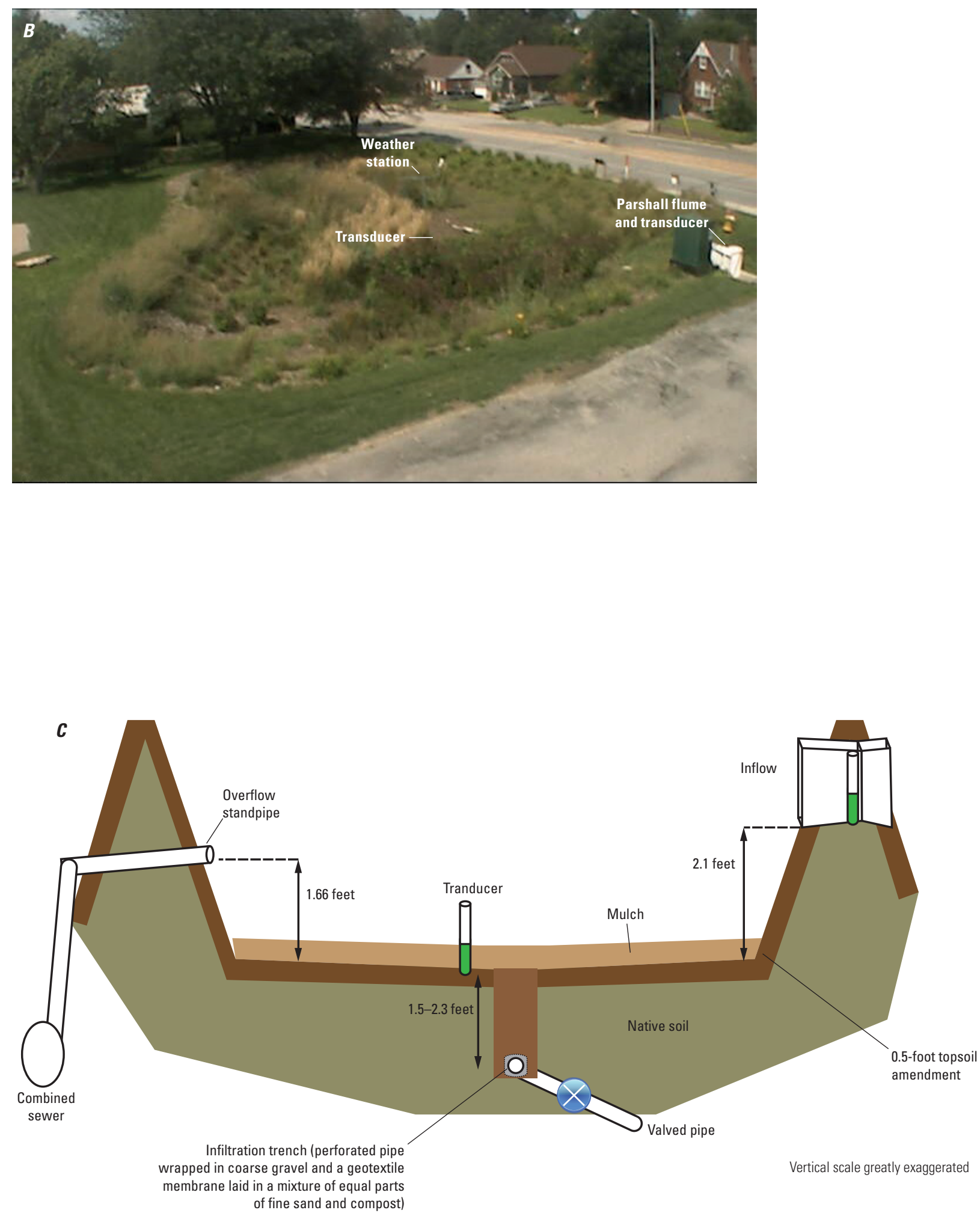

Figure 3. Bioretention garden at the Eastern Nebraska Office on Aging site, Omaha, Nebraska. $A$, drainage area and bioretention garden layout; $B$, photo showing bioretention garden and monitoring equipment as viewed from east of the bioretention garden on September 1, 2014; and $C$, cross-sectional sketch of the bioretention garden.-Continued 


\section{Stormwater Inflow Volume}

Stormwater inflow volume to the bioretention gardens was measured using a Parshall flume with an attached stilling well. For both bioretention gardens, the stormwater runoff was directed into a channel and routed through a Parshall flume with a 9-in. contraction before entering the bioretention gardens. Vented submersible pressure transducers were used to measure the water level in the stilling well using methods described in Sauer and Turnipseed (2010). The water level was used in the Parshall flume equation to determine stormwater inflow (Bureau of Reclamation, 2001):

$$
Q_{S W}=C h_{a}^{n}
$$

where

$$
\begin{gathered}
Q_{S W} \quad \text { is the stormwater inflow, in cubic feet per } \\
\text { second; } \\
\text { is a size-specific coefficient of discharge, or } \\
3.07 \text { for the 9-inch flume contraction; } \\
h_{a} \quad \text { is the measured water level in the stilling } \\
\text { well, in feet; and } \\
\text { is a size-specific exponent, or } 1.53 \text { for the } \\
\text { 9-inch flume contraction. }
\end{gathered}
$$

A stormwater inflow volume, $V_{S W}$, was obtained by multiplying each $Q_{S W}$ measurement by the corresponding measurement interval and summing those individual volumes within a given rainfall event. To display the data in units of length (for example, feet), the volumes (for example, cubic feet) were divided by the surface area (square feet) of the bioretention garden. The result of this calculation was multiplied by 12 to display the data in inches.

The design of the DCHC bioretention garden provided little free board between the bottom of the inflow channel and the maximum ponding depth in garden 1. Ponding depths greater than $0.7 \mathrm{ft}$ above the bottom of garden 1 inundated the Parshall flume (fig. 2C) and invalidated the flow relation above those depths. Consequently, the larger magnitude rainfall events that produced ponding depths exceeding $0.7 \mathrm{ft}$ had to be omitted from the analyses of the DCHC bioretention garden.

\section{Overflow}

Each of the bioretention gardens had overflow standpipes that allowed for outflow to the storm sewer system when the water level exceeded the height of the standpipes. At the DCHC bioretention garden, the overflow height corresponded to $0.39 \mathrm{ft}$ above the land surface of garden 1 (fig. $2 C$ ). At the ENOA bioretention garden, the overflow height corresponded to $1.66 \mathrm{ft}$ above the land surface (fig. $3 C$ ). Water depths in each of the bioretention gardens were measured using vented submersible pressure transducers (Sauer and Turnipseed, 2010) installed in the bottom of the gardens. During the monitoring period, water depths did not exceed $1.66 \mathrm{ft}$ at the ENOA bioretention garden. In contrast, water depths at the DCHC bioretention garden frequently exceeded $0.39 \mathrm{ft}$. Slotted grates placed on top of the standpipes (fig. $4 A$ ) prevented debris from entering the storm sewer but also complicated the estimate of overflow through the standpipes for the DCHC bioretention garden. Johnson and Chang (1984) characterized flow through grates using a combination of the weir spillway equation (equation 3) and the orifice flow equation (equation 4) as follows:

$$
Q_{O F, \text { weir }}=3.0 P h^{1.5}
$$

where
QOF,weir

3.0

$P$

(1)

$h \quad$ is the water depth above the overflow grate, in feet.

$$
Q_{O F, \text { orifice }}=0.67 A \sqrt{2 g h}
$$

where

$$
\begin{array}{cc}
Q_{O F, \text { orfice }} & \begin{array}{c}
\text { is the overflow estimated from equation } 3 \\
\text { (orifice flow), in cubic feet per second; }
\end{array} \\
A & \begin{array}{r}
\text { is the total slot area of the grate (0.32 square } \\
\text { foot for the Douglas County Health Center } \\
\text { bioretention garden); }
\end{array} \\
g \quad \begin{array}{l}
\text { is the gravitational constant (32.2 feet per } \\
\text { second squared); and }
\end{array} \\
h \quad \begin{array}{l}
\text { is the water depth above the overflow grate, in } \\
\text { feet. }
\end{array}
\end{array}
$$

A relation between overflow $\left(Q_{O F}\right)$ and depth above the overflow standpipe was developed using equations 3 and 4 (fig. 4B). At low values of $h$, overflow is governed by the hydraulic conditions of weir flow. As the water depth increases into intermediate values of $h$, overflow transitions to orifice flow. In this intermediate range of $h$, a vortex appears over the grate, and both of the equations overestimate flow; however, accounting for this transitional overestimation is not well defined in the literature. Discussions with the manufacturer of the grates led to the following approach: (1) the intermediate range was defined as those values of $h$ where the weir and orifice equations (equations 3 and 4) produced overflow estimates within 10 percent of one another, and (2) the overflow within the intermediate range was considered to be 90 percent of the mean values calculated from equations 3 and 4 . Based on the geometry of the DCHC grate, this intermediate range was at $h$ values between 0.16 and $0.19 \mathrm{ft}$. At $h$ values greater than the intermediate range, overflow is governed by orifice flow. 

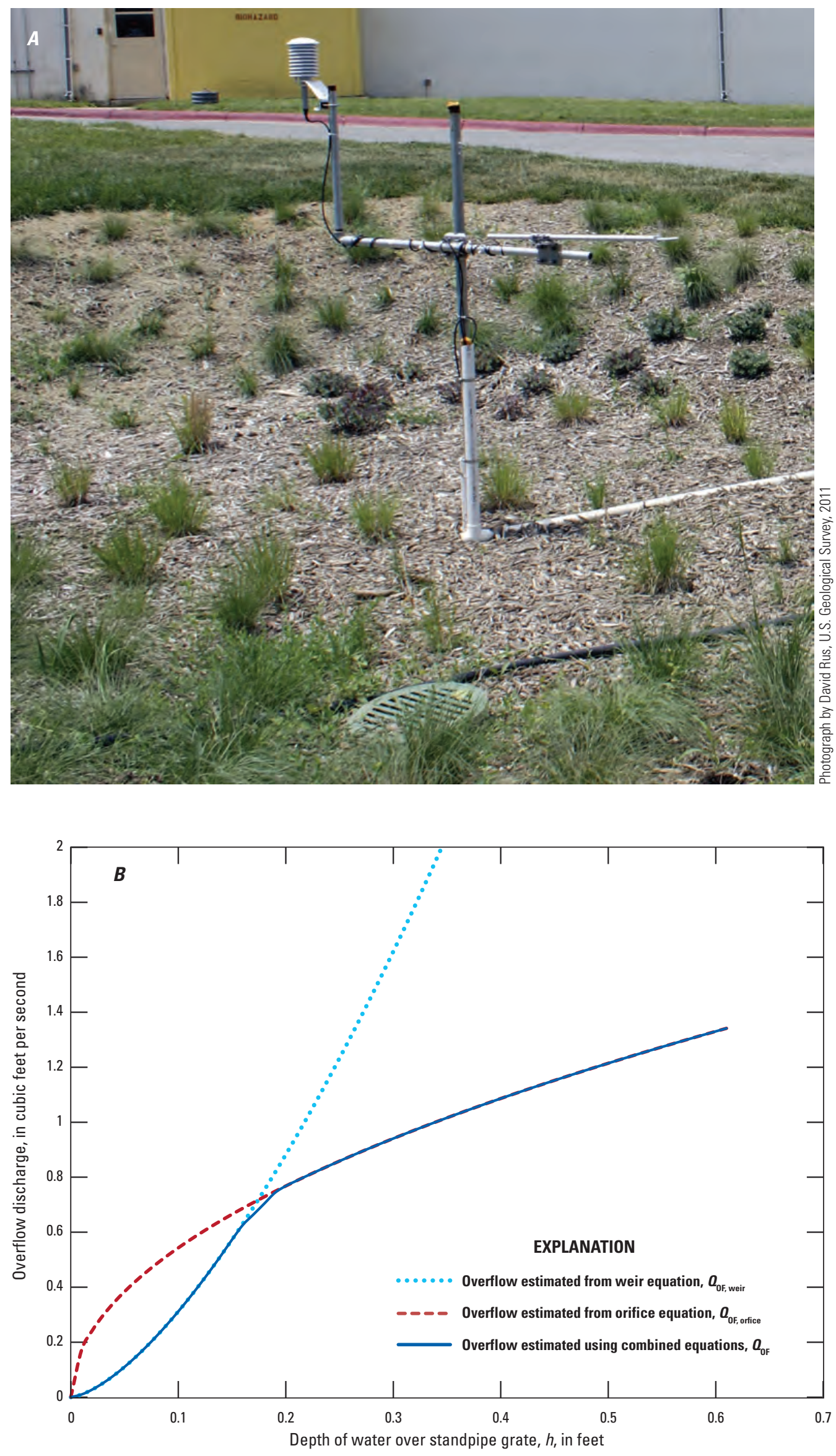

Figure 4. A slotted grate affects overflow estimates at the Douglas County Health Center bioretention garden. $A$, photograph of a slotted grate covering the overflow standpipe and $B$, the relation of overflow to water depth above the standpipe at the garden. 
An assumption for this approach to estimating overflow was that the grate over the standpipe was never clogged (partially or entirely) by debris; however, in reality, this assumption was not always met. Debris was periodically cleaned from the grate, but the level of clogging and frequency of cleaning were not documented; therefore, the computation of overflow may overestimate its true value. Similar to stormwater inflow, the outflow volume by way of the overflow standpipe, $V_{O F}$, was obtained by multiplying each $Q_{O F}$ measurement by the corresponding measurement interval and by summing those individual volumes within a given rainfall event. To display the data in units of length (for example, feet), the volumes (for example, cubic feet) were divided by the surface area (square feet) of the bioretention garden. The result of this calculation was multiplied by 12 to display the data in inches.

\section{Evapotranspiration}

To determine the amount of water that was lost to the atmosphere, evapotranspiration (ET) was calculated at each bioretention garden by scaling the reference evapotranspiration $\left(E T_{0}\right)$ by a landscape coefficient. Measurements of net radiation, air temperature, relative humidity, and wind speed were used to calculate daily $E T_{0}$ using the Penman-Monteith equation (Monteith and Unsworth, 1990; Allen and others, 1998). Reference evapotranspiration represents $E T$, in inches, over a well-watered grass of uniform height that completely shades the ground (Allen and others, 1998). To adjust the $E T_{0}$ to represent the actual $E T$ of the bioretention gardens, a weighted landscape coefficient $(K L)$ was used (Costello and others, 2000). The landscape coefficient modifies the commonly used crop coefficient approach of Allen and others (1998) by accounting for species type, density, and microclimate using the following equation:

$$
K_{L}=K_{s} \times K_{d} \times K_{m c}
$$

where

$$
\begin{array}{cl}
K_{L} & \text { is the landscape coefficient, } \\
K_{s} & \text { is the species factor, } \\
K_{d} & \text { is the density factor, and } \\
K_{m c} & \text { is the microclimate factor. }
\end{array}
$$

Costello and others (2000) developed the landscape coefficient method for California landscapes and provide ranges of appropriate values for species type, density, and microclimate. The climatic and soil differences between California and Nebraska introduce the potential for error that is primarily manifested in the species factor. The water-use characteristics of a particular species may differ between the two geographical regions. However, the landscape coeffiecient method was considered superior to the standard crop coefficient approach because crop coefficients do not exist for the plants within the bioretention garden. In addition, $K L$ values have been used to estimate $E T$ of rain gardens in Wisconsin (Selbig and Balster, 2010). For the two Omaha bioretention gardens, the median values for the species type factor were assigned to each plant species present in the bioretention gardens. Because the bioretention gardens were only constructed a year before the monitoring period, the plantings were not fully established, and an increase in plant density during the monitoring period was not indicated. As a result, a low plant density factor of 0.7 was assigned to each bioretention garden. A microclimate factor value of 1.0 was applied to both monitoring locations because the reference evapotranspiration stations for both sites were located in the gardens and microclimate adjustments would be accounted for in the calculated $E T_{0}$. For each species, a landscape coefficient was calculated using equation 5 and then weighted based on the percentage of the area each plant species occupied that was determined by planting areas in the design plans (Paul Woodward, Olsson Associates, written commun., 2010; table 1). The weighted $K L$ values for the DCHC and ENOA bioretention gardens were 0.25 and 0.30 , respectively. The landscape coefficient was then multiplied by $E T_{0}$ to determine the actual $E T$ at each bioretention garden. To display the data in in units of volume (for example, cubic feet), the actual ET (inches) was divided by 12 to convert to feet and then multiplied by the surface area of the bioretention garden (square feet).

\section{Subsurface Storage}

Subsurface storage, VSS, was calculated using the water balance equation. Because the other components were either measured or were zero, subsurface storage was estimated as the residual by rearranging equation 1 as follows:

$$
V_{S S}=V_{P}+V_{S W}-V_{O F}-V_{E T}
$$

where

$V_{S S} \quad$ is the volume of subsurface storage in the soil system from the bioretention garden,

$V_{P} \quad$ is the volume of precipitation that falls directly into the bioretention garden, $V_{S W} \quad$ is the volume of stormwater inflow to the bioretention garden,

$V_{O F} \quad$ is the volume of outflow from the bioretention garden by way of the overflow standpipe, and

$V_{E T} \quad$ is the volume of evapotranspiration from the bioretention garden.

To display the data in units of length (for example, feet), the volumes (for example, cubic feet) were divided by the surface area (square feet) of the bioretention garden. The result of this calculation was multiplied by 12 to display the data in inches.

The estimation of subsurface storage as the residual of the remaining components of the water balance neglects the effects of measurement error. The precision of tipping bucket rain gages varied with rainfall intensity; however, the precision generally varied by 2.9 percent when measured at a 15-minute interval (Ciach, 2002). Parshall flumes produce 
Table 1. Summary of plant species and calculated landscape coefficient for the bioretention gardens at the Douglas County Health Center and Eastern Nebraska Office on Aging sites.

$\left[K_{s}\right.$, species factor; $K_{d}$, density factor; $K_{m c}$, microclimate factor; $K_{L}$, landscape coefficient; --, no value $]$

\begin{tabular}{|c|c|c|c|c|c|}
\hline Plant species & $\begin{array}{c}\text { Percentage of } \\
\text { area }\end{array}$ & $K_{s}$ & $K_{d}$ & $\boldsymbol{K}_{m c}$ & $K_{L}$ \\
\hline \multicolumn{6}{|c|}{ Douglas County Health Center } \\
\hline Sorghastrum nutans & 11.1 & 0.5 & 0.7 & 1 & 0.35 \\
\hline Sedum spp. (some are Hylotelephium) & 8.0 & 0.2 & 0.7 & 1 & 0.14 \\
\hline Schizachyrium scoparium & 22.8 & 0.2 & 0.7 & 1 & 0.14 \\
\hline Rudbeckia spp. & 4.1 & 0.5 & 0.7 & 1 & 0.35 \\
\hline Liatris spicata & 14.9 & 0.5 & 0.7 & 1 & 0.35 \\
\hline Calamagrostis $x$ acutiflora & 6.8 & 0.5 & 0.7 & 1 & 0.35 \\
\hline Bouteloua gracilis & 7.7 & 0.2 & 0.7 & 1 & 0.14 \\
\hline Asclepias incarnata & 17.1 & 0.5 & 0.7 & 1 & 0.35 \\
\hline Andropogon gerardii & 7.3 & 0.2 & 0.7 & 1 & 0.14 \\
\hline Weighted $K_{L}$ & -- & -- & -- & -- & 0.25 \\
\hline \multicolumn{6}{|c|}{ Eastern Nebraska Office on Aging } \\
\hline Sedum spp. (some are Hylotelephium) & 6.4 & 0.2 & 0.7 & 1 & 0.14 \\
\hline Schizachyrium scoparium & 6.4 & 0.2 & 0.7 & 1 & 0.14 \\
\hline Rudbeckia spp. & 6.6 & 0.5 & 0.7 & 1 & 0.35 \\
\hline Monarda didyma & 5.5 & 0.5 & 0.7 & 1 & 0.35 \\
\hline Miscanthus sinensis & 6.4 & 0.5 & 0.7 & 1 & 0.35 \\
\hline Liatris spicata & 6.8 & 0.5 & 0.7 & 1 & 0.35 \\
\hline Hemerocallis spp. & 7.7 & 0.5 & 0.7 & 1 & 0.35 \\
\hline Helenium autumnale & 10.6 & 0.5 & 0.7 & 1 & 0.35 \\
\hline Eupatorium spp. & 6.2 & 0.5 & 0.7 & 1 & 0.35 \\
\hline Cornus sericea & 4.3 & 0.8 & 0.7 & 1 & 0.56 \\
\hline Calamagrostis $x$ acutiflora & 11.2 & 0.5 & 0.7 & 1 & 0.35 \\
\hline Bouteloua gracilis & 8.2 & 0.2 & 0.7 & 1 & 0.14 \\
\hline Asclepias incarnata & 7.2 & 0.5 & 0.7 & 1 & 0.35 \\
\hline Andropogon gerardii & 6.8 & 0.2 & 0.7 & 1 & 0.14 \\
\hline Weighted $K_{L}$ & -- & -- & -- & -- & 0.30 \\
\hline
\end{tabular}

flow estimates within 5 percent of actual values (Bureau of Reclamation, 2001; Heiner and others, 2010). The other two components, VOF and VET however, are much more poorly constrained in their precision. The values of $V_{O F}$ are assumed to be within 25 percent of actual values, and because of the grate clogging, the flow volume has a tendency to be overestimated. Because of the dependence on several empirical factors used in the estimation of VET, this component is assumed to vary by 50 percent on a daily basis but is likely to be more accurate at a monthly or greater time step. Because of the errors associated with the VSS component being calculated as the residual, VSS is tabulated in the report as a range to account for the uncertainty in the actual value. This range was calculated by finding the maximum and minimum values using the accuracy of the measurements for each component that were discussed above.

\section{Rainfall Event Duration Determination}

The performance of the bioretention gardens was evaluated for a series of rainfall events that will be referred to as "events" throughout report. The start of an event was determined when rainfall began at the site. The end of an event was determined when the water level was equal to zero in the stilling well of the inflow flume or when the water level in the bioretention garden was zero, whichever occurred last. 


\section{Water Balance Monitoring}

Water balance monitoring at the DCHC bioretention garden was analyzed on a rainfall event basis and also summarized for the monitoring period. No overflow events were recorded at the ENOA bioretention garden; therefore, only a monitoring period analysis of the water balance was tabulated for that site. The lack of overflows could be because of the larger available storage volume per acre $\left(4,500 \mathrm{ft}^{3}\right.$ per acre) at the ENOA site compared to the $538 \mathrm{ft}^{3}$ per acre at the DCHC site, indicating that the ENOA bioretention garden could be oversized for the drainage area.

\section{Douglas County Health Center Site}

At the DCHC bioretention garden, water balance components of precipitation, stormwater inflow volume, outflow volume by way of the overflow standpipe, evapotranspiration, and subsurface storage were tabulated by event and on annual (excluding winter) time steps for the monitoring period. As stated in the "Stormwater Inflow Volume" section, events that produced ponding depths higher than $0.7 \mathrm{ft}$ were excluded from the analyses. Although the high volume events represented only 26 out of 281 events, they represented 43 in. or 48 percent of the total rainfall of 89 in. recorded during the monitoring period. As a result, monthly or annual performance metrics and totals are affected because these large rainfall events would have more outflow volume than the rainfall events that were assessed.

\section{Performance on an Event Basis}

Events for the bioretention garden at the DCHC site were separated using the criteria described previously in the "Methods" section. At the DCHC bioretention garden, 255 of the 281 events were included in the analysis, and 39 of the 255 events led to overflow of the garden. The analyzed events had a minimum rainfall of 0.01 in. and a maximum rainfall of 1.4 in., with a minimum rainfall intensity of 0.04 inch per hour and a maximum intensity of 2.1 inches per hour. The storms captured by the monitoring characterize small to medium size events.

Performance on a volume-reduction basis was evaluated by comparing total event rainfall to percent reduction of inflow volume (fig. $5 A$ ) and by comparing total inflow volume to total outflow volume (fig. $5 B$ ). The bioretention garden reduced inflow volumes from a minimum of 33 percent to 100 percent (a complete reduction in inflow volume) depending on the size of the event. Although variable, the percent reduction of the inflow volume tended to decrease with increasing total event rainfall. The line of equality on figure $5 B$ shows the stormwater response that would have taken place had the garden not been installed. As expected, all of the outflows from the garden were to the right of the line of equality, which indicates that the garden reduced outflow volume, and all event total inflows less than the garden volume $\left(700 \mathrm{ft}^{3}\right)$ were 100 percent captured. Of the 67 events that produced inflow volumes greater than $700 \mathrm{ft}^{3}$ but less than 3,000 $\mathrm{ft}^{3}, 38$ events were completely captured. A linear regression line was fit to events where the inflow volume exceeded 1,000 $\mathrm{ft}^{3}$ and was less than 5,400 $\mathrm{ft}^{3}$. Some of the events at the site that had inflow volumes less than 5,400 $\mathrm{ft}^{3}$ may have been excluded in this analysis because an event that had an inflow less than $5,400 \mathrm{ft}^{3}$ could exceed the $0.7-\mathrm{ft}$ ponding depth limitation and, therefore, would have been excluded. The linear regression line had a slope of 0.59 , indicating that when the garden was overflowing, only 59 percent of the inflow was outflow (or a volume reduction of 41 percent). This slope of 0.59 at the DCHC bioretention garden also is similar to the slope of 0.72 at a bioretention garden in Maryland (Davis and others, 2012). The variability in the relation shown in figure 5 indicated by the coefficient of determination of 0.61 , where unity would be a perfect correspondence between inflow and a proportional volume reduction as outflow, also indicates that rainfall intensity could be one of the factors affecting the reduction in volume. For example, the 18-hour event on September 10, 2013, had a total rainfall of 0.72 in., a maximum intensity of 0.32 inch per hour, with a 5 -day time period since the previous event and produced 3,000 $\mathrm{ft}^{3}$ of inflow that was contained by the garden. In contrast, the 6-hour event on October 22, 2014 , had a total rainfall of 0.76 in., a maximum intensity of 0.88 inch per hour, with a 9-day time period since the previous event and produced 3,100 $\mathrm{ft}^{3}$ of inflow and $807 \mathrm{ft}^{3}$ of outflow. Other factors that may contribute to the variability in volume reduction shown in figures $5 A-5 B$ could be antecedent moisture conditions of the bioretention garden and the timing and duration of the high intensity rainfall in the event.

In addition to volume reduction, another benefit of bioretention gardens is the ability to reduce peak inflow rates. To assess how well the garden reduces stormwater peak inflow rates, peak inflows were plotted against peak outflows measured at the bioretention garden (fig. 6). The line of equality shown in figure 6 indicates the stormwater peak that would have recorded in the absence of the bioretention garden. As expected, all of the peak outflows plot to the right of the line of equality. Only 39 of the 255 analyzed events caused outflow through the overflow standpipe, indicating complete capture of stormwater for all other events. Of those 39 events having overflow, the mean reduction in peak inflows was 63 percent. Reductions in the peak inflows varied between 17 and 100 percent. Similar to the volume reduction, a threshold seemed to exist above which peak outflows were observed; however, variability in the peak reduction response was greater than in the volume-reduction response. Consequently, a linear relation between peak inflow and peak outflow was not developed. The variation in the peak inflow reduction possibly can be attributed to rainfall intensity and to the timing and duration of the high intensity rainfall of the event. 

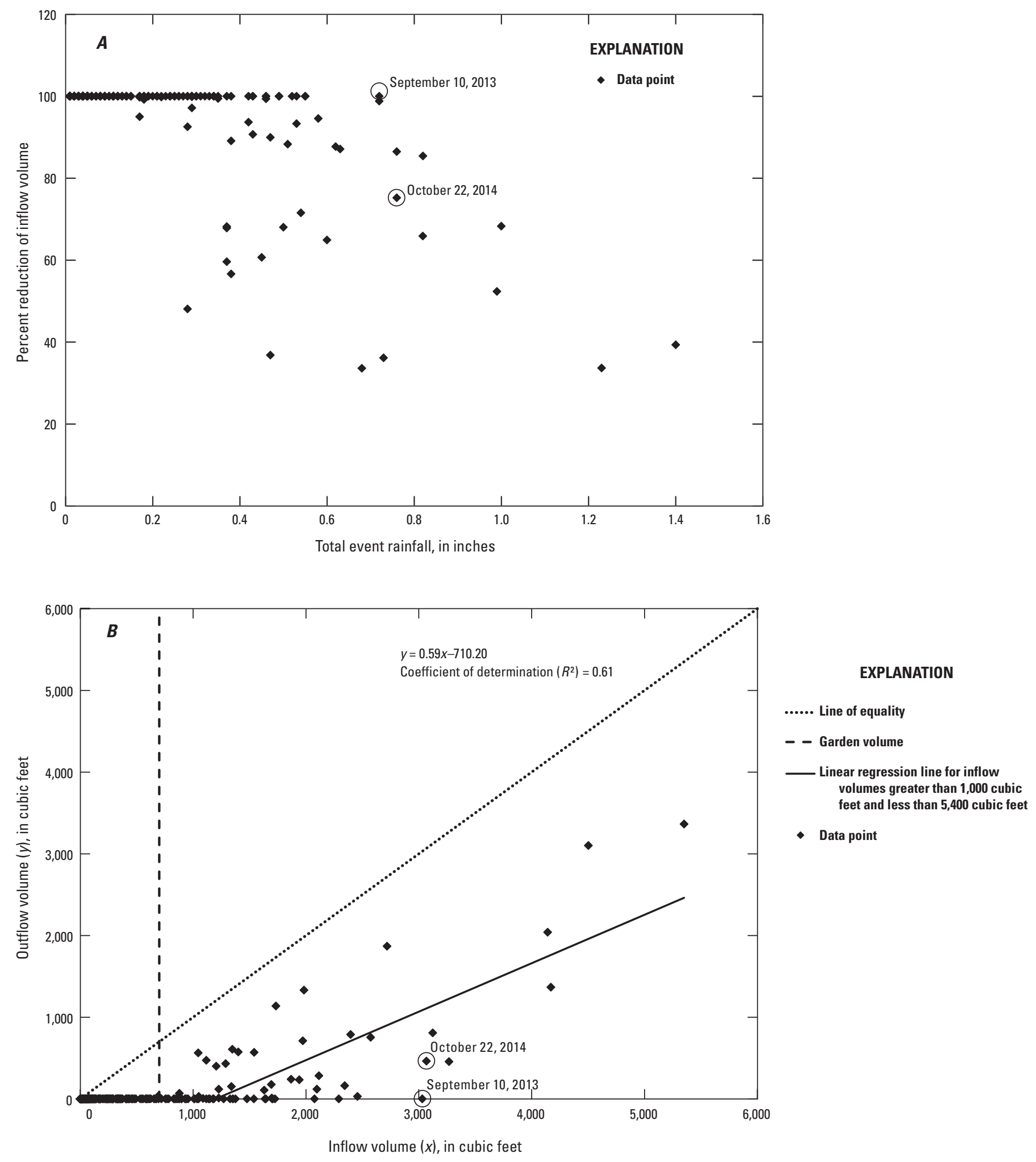

Figure 5. Performance measures at the bioretention garden at the Douglas County Health Center site. $A$, relation between total event rainfall and percent reduction of inflow volume; $B$, relation between inflow volume and outflow volume for measured events. 


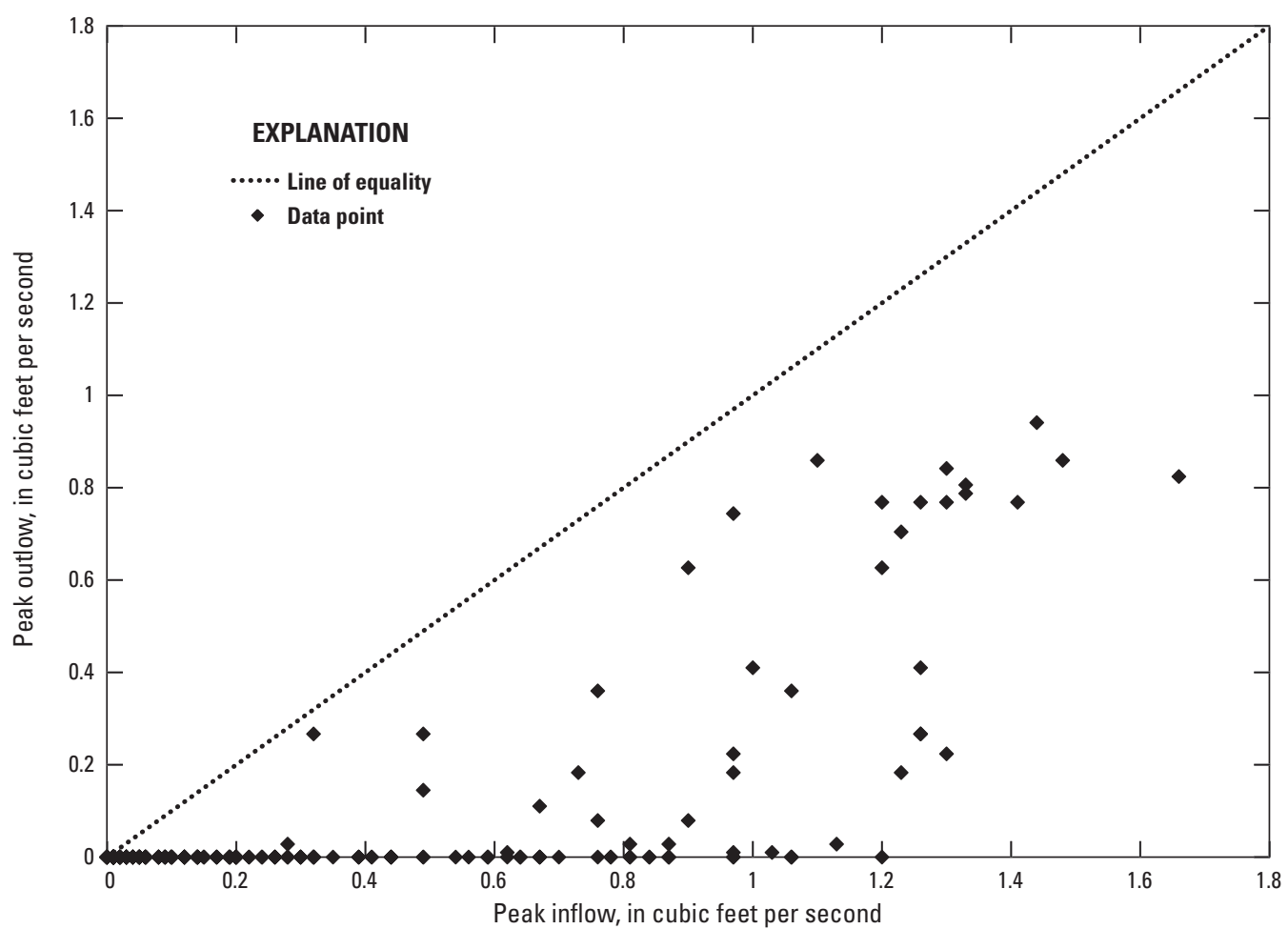

Figure 6. Relation between peak inflow rate and peak outflow rate for measured events at the Douglas County Health Center bioretention garden.

\section{Monitoring Period Summary}

Water balance components for measured events at the DCHC bioretention garden were tabulated for each monitoring period; totals and the amounts of individual components are shown in figure 7 and listed in table 2, which also includes percentages of total outputs for the three output components (subsurface storage, outflow volume, and evapotranspiration). Subsurface storage composed the largest percentage of output from the bioretention garden ranging from a minimum of 64 percent to a maximum of 98 percent, and the total for all 4 years was 73-93 percent. Outflow was the second largest percentage for outputs ranging from a minimum of 7 percent to a maximum of 20 percent, and the total was 14 percent for the monitoring period. Evapotranspiration generally was constant, accounting for about 2 percent of the output, except for the exceptionally hot and dry year of 2012 when the percentage lost to evapotranspiration was double (4 percent) than that of the other 3 years. This higher evapotranspiration value in 2012 was due to a drought that affected the region from November 2011 through March 2013 (National Drought Mitigation Center, 2015).

\section{Eastern Nebraska Office on Aging Site}

The ENOA bioretention garden did not record any overflow events and had a total reduction in flow; therefore, data were not available for an event-based overflow analysis at the

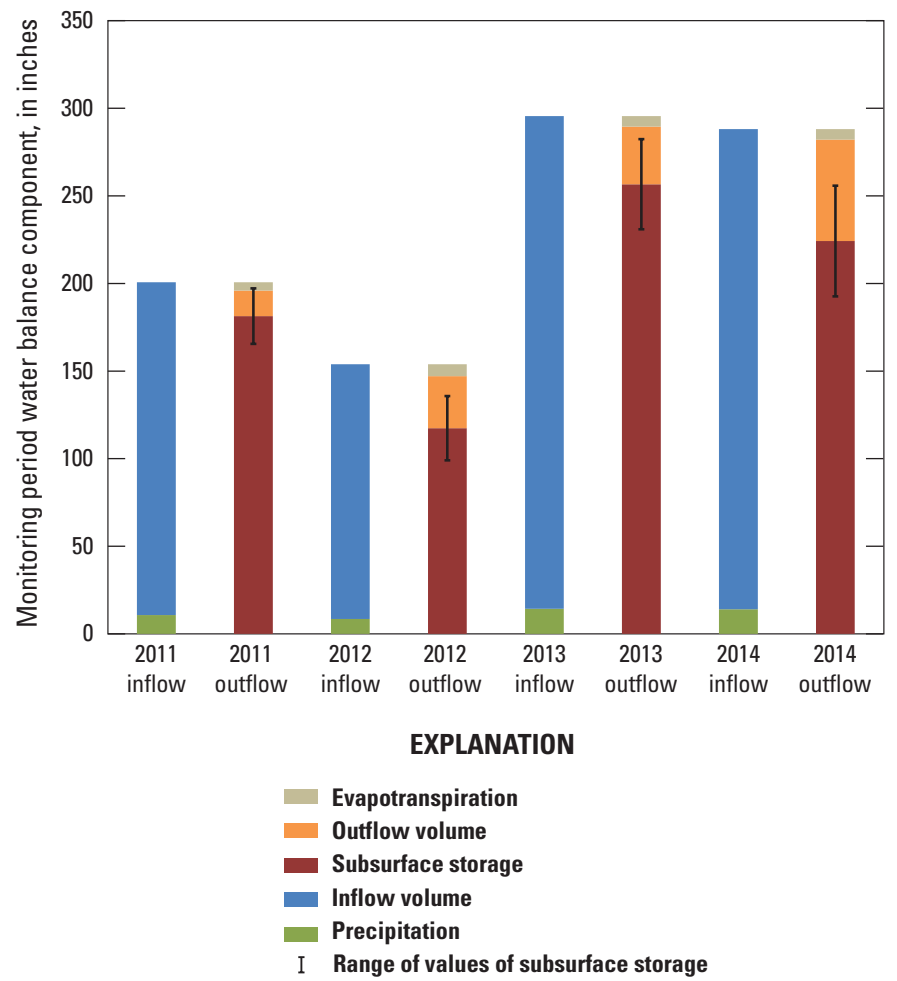

Figure 7. Annual water balance components for measured events during 2011-14, normalized to the bioretention garden area at the Douglas County Health Center site. 


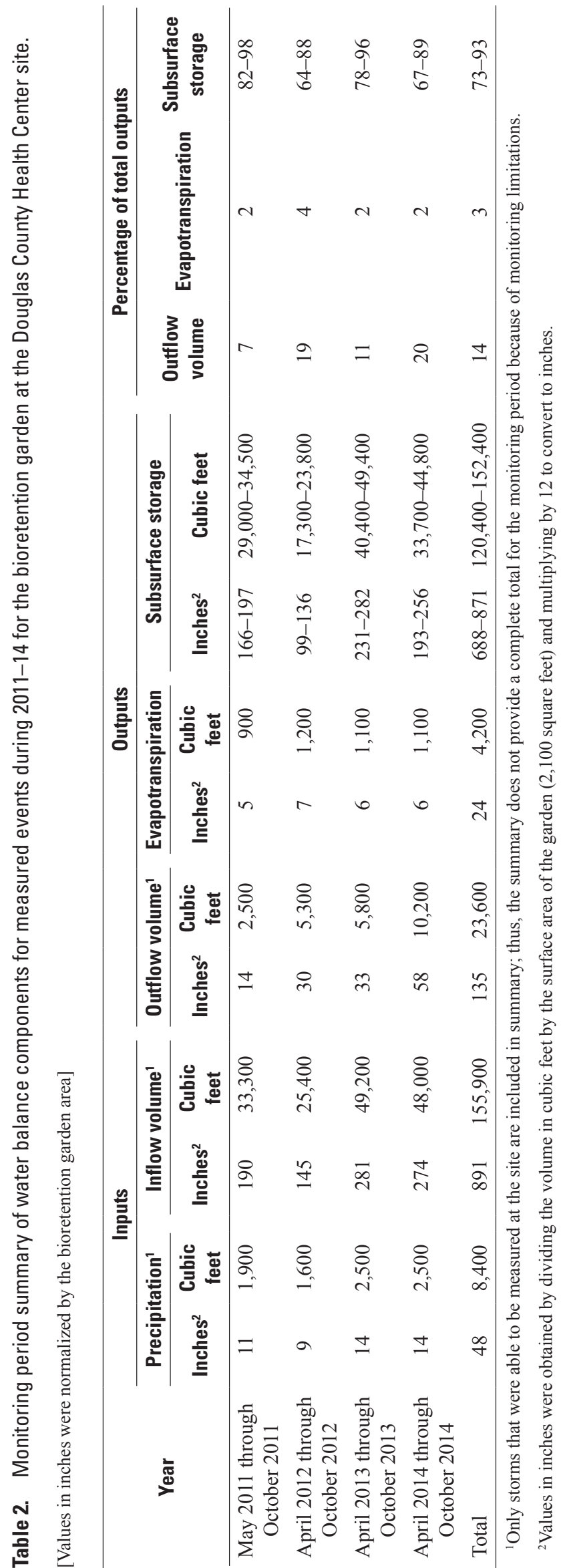

bioretention garden. Water balance components were summarized on a monitoring period basis during 2011-14.

Water balance components for all events at the ENOA bioretention garden were tabulated and summarized for each monitoring period; totals and the amounts of individual components are shown in figure 8 and listed in table 3 , which also includes percentages of total output for the three output components (subsurface storage, evapotranspiration, and outflow volume). The large increase in the amount of inflow volume measured during 2011-12 compared to inflow volume measured during 2013-14 is shown in figure 8. The reason for this increase in inflow is because of modifications to the parking lot drain inlets at the ENOA site and because of the increased drainage area at the site as described previously in the "Study Area" section. Subsurface storage composed the largest percentage of output from the bioretention garden ranging from a minimum of 48 percent to a maximum of 100 percent, and the total for all 4 years was $87-99$ percent. Evapotranspiration ranged from a minimum of 3 percent in 2014 to a maximum of 32 percent during the drought in 2012. For the monitoring period, evapotranspiration composed 5 percent of the total outputs from the bioretention garden. Because the ENOA bioretention garden did not record any overflow events, the outflow was zero, and the bioretention garden reduced 100 percent, or $115,700 \mathrm{ft}^{3}$, of the amount of stormwater flow that would have been output to the combined sewer system during the 2011-14 monitoring period.

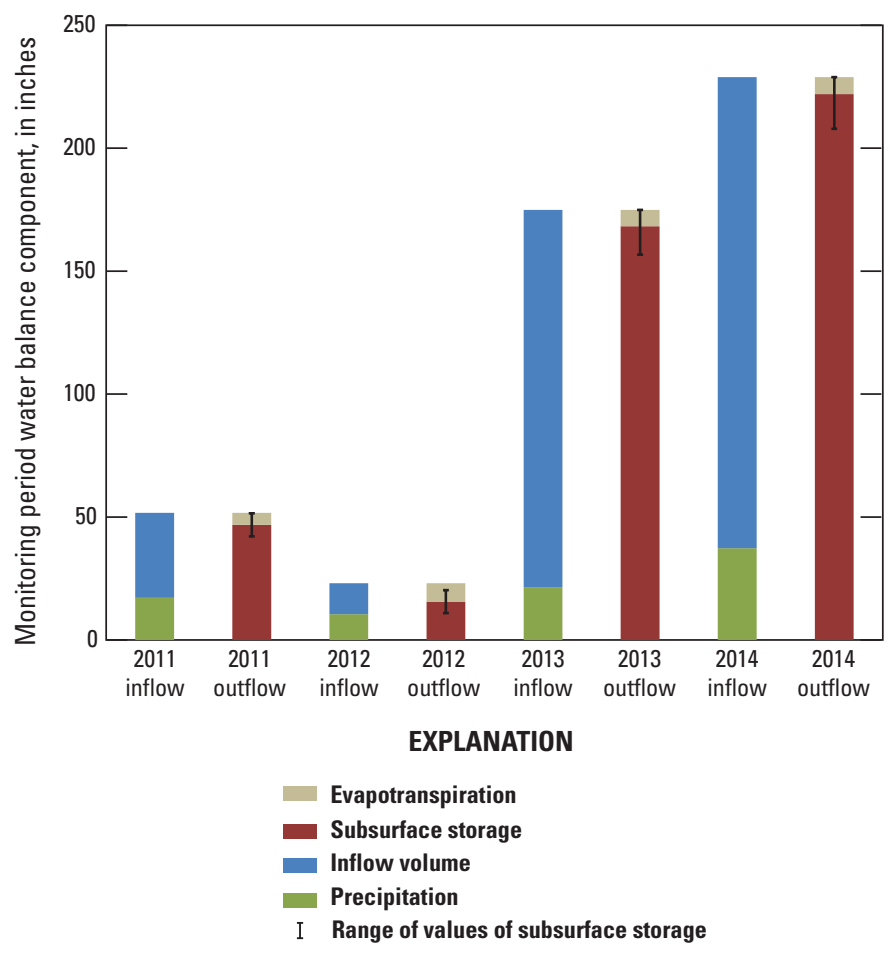

Figure 8. Annual water balance components for all events during 2011-14, normalized to the bioretention garden area at the Eastern Nebraska Office on Aging site. 


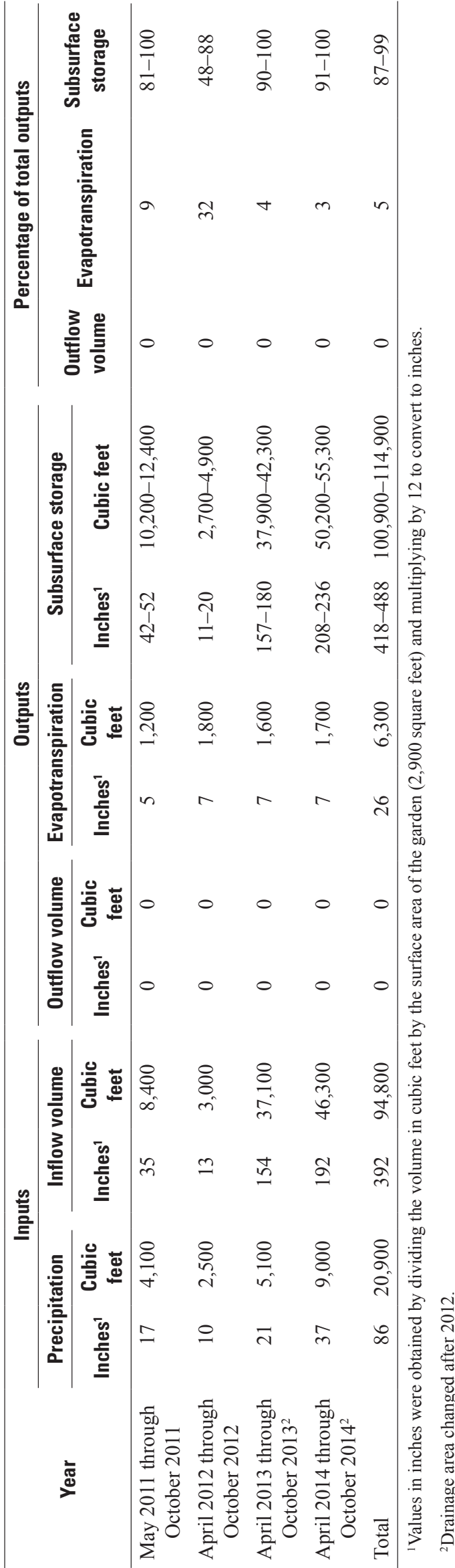

Considering the water balance monitoring at both bioretention gardens, a small percentage of the outputs was attributed to evapotranspiration on an annual basis ( 3 percent at the DCHC site [table 2] and 5 percent at the ENOA site [table 3]), which indicates that vegetative water uptake is not a primary factor in the water budget. The evapotranspiration values (5-7 in.) are less than published annual mean estimates of 21-27 in. for the study region (Szilagyi, 2015); however, this deviation is mainly attributed to the low plant species factors in the landscape coefficient method that was used to scale the reference evapotranspiration $\left(E T_{0}\right)$ as described in the "Evapotranspiration" section. Vegetation, however, is important in the function of the bioretention garden because vegetation aids in maintaining infiltration rates through combating soil compaction in the gardens (Hatt and others, 2009).

\section{Summary}

Urbanization can radically alter the flow regime of a stream system by creating impermeable areas that favor stormwater runoff instead of infiltration and by constructing drainage networks that quickly transport the stormwater out of the urban area. Areas that are drained by combined sewer systems - where stormwater and sanitary sewage are combined and can be released untreated into streams during rainfall events - present a greater challenge to stormwater management as a result of the additional human-health threats associated with stormwater runoff. In response, stormwater best management practices are used to reduce stormwater effects. A bioretention garden is one type of stormwater best management practice. In the case of combined sewer systems such as in Omaha, Nebraska, bioretention gardens have the potential to decrease the frequency and magnitude of instances when untreated sewage is released into receiving waters. To better understand the performance of bioretention gardens in eastern Nebraska, the U.S. Geological Survey, in cooperation with Douglas County Environmental Services and the Nebraska Environmental Trust, assessed the water balance of two bioretention gardens by monitoring the amount of stormwater entering and leaving the gardens. The gardens are on the Douglas County Health Center campus approximately two blocks south of 40th and Pacific Streets and on the Eastern Nebraska Office on Aging property at the southwest corner of 42nd and Center Streets. Water balance components of precipitation, stormwater inflow, outflow, reference evapotranspiration, and subsurface storage were either measured directly or computed. Water balance data were collected at the two bioretention gardens from May through October in 2011 and from April through October in 2012, 2013, and 2014.

At the Douglas County Health Center site, bioretention garden performance on a volume-reduction basis was evaluated by comparing total inflow volume to total outflow volume. The bioretention garden reduced inflow volumes from a minimum of 33 percent to 100 percent (a complete 
reduction in inflow volume) depending on the size of the event. Although variable, the percent reduction of inflow volume tended to decrease with increasing total event rainfall. To assess how well the garden reduces stormwater peak inflow rates, peak inflows were plotted against peak outflows measured at the bioretention garden. Only 39 of the 255 events had any overflow, indicating 100 percent peak reduction in the other events. Of those 39 events having overflow, the mean peak reduction was 63 percent.

No overflow events were recorded at the bioretention garden at the Eastern Nebraska Office on Aging site; therefore, data were not available for an event-based overflow analysis. Monitoring period summary of the water balance at both bioretention gardens indicates that most of the stormwater in the bioretention gardens is stored in the subsurface. A small percentage of the outputs was attributed to evapotranspiration on an annual basis (3 percent at Douglas County Health Center site and 5 percent at Eastern Nebraska Office on Aging site), which indicates that vegetative water uptake is not a primary factor in the water budget.

\section{References Cited}

Allen, R.G., Pereira, L.S., Raes, D., and Smith, M., 1998, Crop evapotranspiration-Guidelines for computing crop requirements: Food and Agriculture Organization of the United Nations, Irrigation and Drainage Paper No. 56, $300 \mathrm{p}$.

Bureau of Reclamation, 2001, Water measurement manual: Bureau of Reclamation Technical Manual, 317 p., accessed June 5, 2015, at http://www.usbr.gov/tsc/techreferences/ mands/wmm/index.htm.

Ciach, G.J., 2002, Local random errors in tipping-bucket rain gauge measurements: Journal of Atmospheric and Oceanic Technology, v. 20, p. 752-759. [Also available at http:// dx.doi.org/10.1175/1520-0426(2003)20<752:LREITB $>2.0$ .CO;2.]

City of Omaha, 2014, Omaha regional stormwater design manual: City of Omaha, Nebr., accessed June 3, 2015, at http://www.omahastormwater.org/orsdm/.

Costello, L.R., Clark, J.R., Jones, K.S., and Matheny, N.P., 2000, A guide to estimating irrigation water needs of landscape plantings in California-The landscape coefficient method and WUCOLS IV: University of California Cooperative Extension, $150 \mathrm{p}$.
Davis, A.P., Traver, R.G., Hunt, W.F., Lee, R., Brown, R.A., and Olszewski, J.M., 2012, Hydrologic performance of bioretention storm-water control measures: Journal of Hydrologic Engineering, v. 17, no. 5, p. 604-614. [Also available at http://dx.doi.org/10.1061/(ASCE)HE.19435584.0000467.]

Fletcher, T.D., Shuster, W., Hunt, W.F., Ashley, R., Butler, D., Arthur, S., Trowsdale, S., Barraud, S., Semadeni-Davies, A., Bertrand-Krajewski, J., Mikkelsen, P.S., Rivard, G., Uhl, M., Dagenais, D., and Viklander, M., 2015, SUDS, LID, BMPs, WSUD and more-The evolution and application of terminology surrounding urban drainage: Urban Water Journal, v. 12, no. 7, p. 525-542. [Also available at http:// dx.doi.org/10.1080/1573062X.2014.916314.]

Hatt, B.E., Fletcher, T.D., and Deletic, A., 2009, Hydrologic and pollutant removal performance of stormwater biofiltration systems at the field scale: Journal of Hydrology, v. 365, nos. 3-4, p. 310-321. [Also available at http://dx.doi. org/10.1016/j.jhydrol.2008.12.001.]

Heiner, B., Barfuss, S.L., and Johnson, M.C., 2010, Conditional assessment of flow measurement accuracy: Journal of Irrigation and Drainage Engineering, v. 137, no. 6, p. 367-374. [Also available at http://dx.doi.org/10.1061/ (ASCE)IR.1943-4774.0000309.]

Johnson, F.L, and Chang, F.F., 1984, HEC 12 drainage of highway pavements: U.S. Department of Transportation, Federal Highway Administration, FHWA-TS-84-202, 195 p.

Monteith, J.L., and Unsworth, M.H., 1990, Principals of environmental physics, (2d ed.): London, Edward Arnold, 289 p.

National Drought Mitigation Center, 2015, Tabular data archive for Nebraska: U.S. Department of Agriculture, accessed March 18, 2015, at http://droughtmonitor.unl.edu/ MapsAndData/DataTables.aspx?NE.

National Oceanic and Atmospheric Administration, 2015a, Data tools-1981-2010 normals: Omaha, Nebr., National Centers for Environmental Information, Omaha Eppley Airfield, accessed March 24, 2015, at http://www.ncdc.noaa. gov/cdo-web/datatools/normals.

National Oceanic and Atmospheric Administration, 2015b, Advanced Hydrologic Prediction Service, QPE-Quantitative Precipitation Estimates: U.S. Department of Commerce, accessed April 10, 2015, at http://water.weather.gov/ precip/.

National Research Council, 2009, Urban stormwater management in the United States: Washington, D.C., National Academies Press, 598 p. 
Sauer, V.B., and Turnipseed, D.P., 2010, Stage measurement at gaging stations: U.S. Geological Survey Techniques and Methods, book 3, chap. A7, 45 p. [Also available at http:// pubs.usgs.gov/tm/tm3-a7/.]

Selbig, W.R., and Balster, Nicholas, 2010, Evaluation of turf-grass and prairie-vegetated rain gardens in a clay and sand soil, Madison, Wisconsin, water years 2004-08: U.S. Geological Survey Scientific Investigations Report 2010-5077, 72 p. [Also available at http://pubs.usgs.gov/ sir/2010/5077/.]
Szilagyi, J., 2015, Nebraska evapotranspiration estimation-Mean annual (2000-2009) evapotranspiration rates in Nebraska: University of Nebraska-Lincoln School of Natural Resources, accessed September 29, 2015, at http:// snr.unl.edu/data/water/evapotranspiration/statewideet.aspx.

U.S. Geological Survey, 2015, USGS surface-water data for the Nation: U.S. Geological Survey, National Water Information System, accessed April 9, 2015, at http://waterdata. usgs.gov/nwis/sw.

Water Environment Federation, 2012, Design of urban stormwater controls: Chicago, Ill., McGraw Hill, 705 p. 
Publishing support provided by:

Rolla Publishing Service Center

For more information concerning this publication, contact:

Director, USGS Nebraska Water Science Center

5231 South 19th Street

Lincoln, Nebraska 68512

(402) 328-4100

Or visit the Nebraska Water Science Center Web site at: http://ne.water.usgs.gov/ 


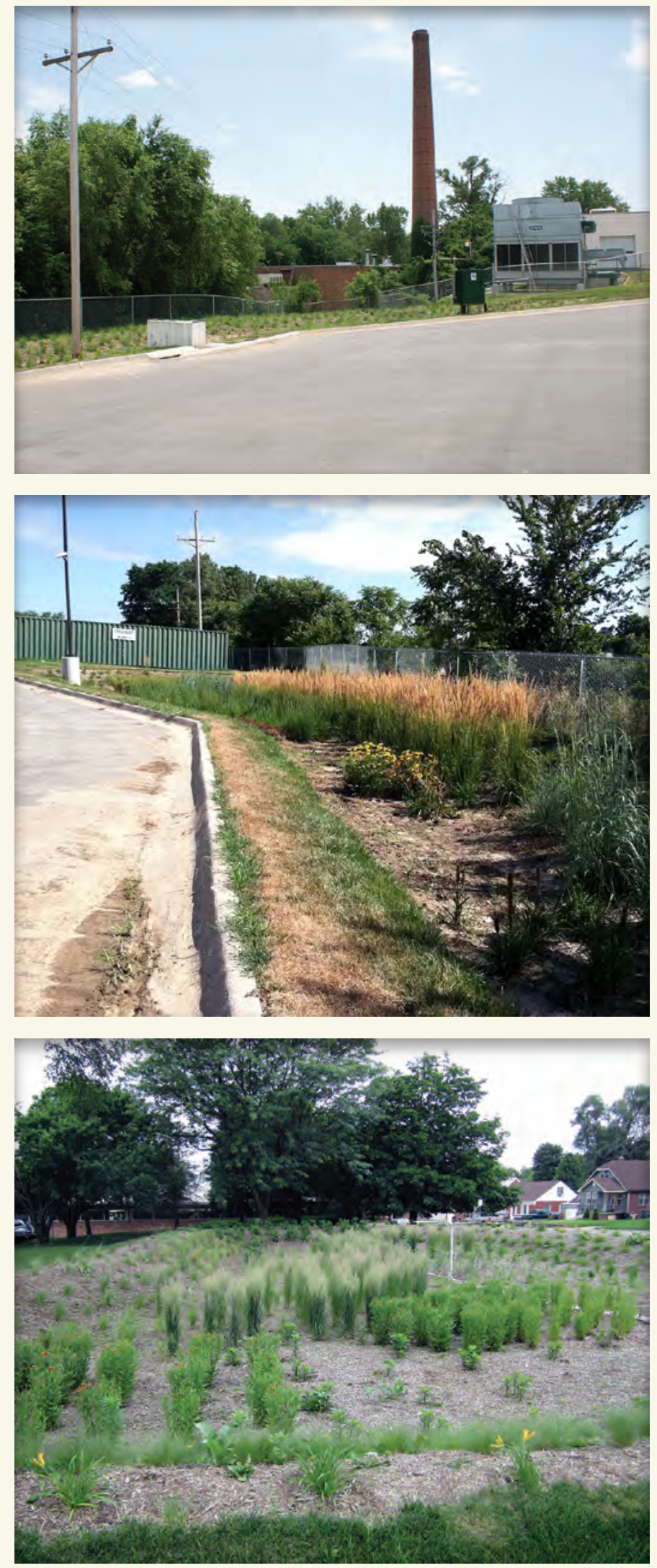